\title{
PENGARUH PEMBERIAN URIN KELINCI TERHADAP SERANGAN Turnip Mosaic Virus (TuMV) PADA TANAMAN KAILAN (Brassica oleraceae var. alboglabra) YANG DIBUDIDAYAKAN SECARA ORGANIK
}

\author{
Fery Abdul Choliq ${ }^{1}$, Mintarto Martosudiro ${ }^{1}$, Qurrota Ayuni Apriliana ${ }^{1}$, Istiqomah ${ }^{2}$ \\ ${ }^{1}$ Jurusan Hama dan Penyakit Tumbuhan Fakultas Pertanian Universitas Brawijaya \\ 2 Fakultas Pertanian Universitas Islam Darul ‘Ulum Lamongan Jawa Timur \\ Korespondensi : feryac@ub.ac.id
}

\begin{abstract}
ABSTRAK
Tanaman kailan memiliki potensi tinggi untuk dikembangkan di Indonesia. Sistem bubidaya yang dapat menghasilkan produk yang berkualitas tinggi yaitu budidaya tanaman kailan secara organik. Budidaya kailan secara organik membutuhkan pemeliharaan yang intensif. Penyakit yang sering menyerang tanaman kailan adalah penyakit mosaik yang disebabkan oleh Turnip Mosaic Virus (TuMV). Tujuan penelitian ini adalah untuk mengetahui pengaruh pemberian pupuk organik cair (poc) dari urin kelinci terhadap serangan virus TuMV pada tanaman kailan serta mengetahui pengaruhnya terhadap pertumbuhan dan produksi tanaman kailan. Penelitian akan dilaksanakan di Komunitas Organik Brenjonk yang berlokasi Kab. Mojokerto pada bulan februari hingga Maret 2016. Penelitian dilakukan menggunakan metode Rancangan Acak Kelompok (RAK) dengan enam perlakuan dan setiap perlakuan diulang sebanyak empat kali. Variabel pengamatan meliputi masa inkubasi dan gejala penyakit, intensitas serangan penyakit, tinggi tanaman, bobot basah tanaman, panjang akar, dan luas daun tanaman. Hasil dari pengamatan menunjukkan bahwa pemberian pupuk organik cair dari urin kelinci dengan konsentrasi $8 \mathrm{ml} / \mathrm{L}$ sampai dengan $32 \mathrm{ml} / \mathrm{L}$ yang diaplikasikan sebanyak 8 kali, dapat memperpanjang masa inkubasi dan tidak dapat menurunkan intensitas serangan TuMV. Hasil dari pengamatan menunjukkan bahwa pemberian pupuk organik cair dari urin kelinci dengan konsentrasi $8 \mathrm{ml} / \mathrm{L}$ sampai dengan $32 \mathrm{ml} / \mathrm{L}$ yang diaplikasikan sebanyak 8 kali pada tanaman kailan dapat meningkatkan pertumbuhan dan produksi tanaman meliputi bobot basah tanaman, tinggi tanaman, panjang akar tanaman dan luas daun tanaman.
\end{abstract}

Kata kunci : urin kelinci, Turnip Mosaic Virus (TuMV), kailan, organik

ABSTRACT

Kai Lan has a high potential for being developed in Indonesia. The cultivation system that can produce high quality product that is organically cultivated of kai Lan. Organic plant cultivation require intensive maintenance. The disease that often attacks kailan plants is a mosaic disease caused by Turnip Mosaic Virus (TuMV). The purpose of this research was to find out the effect of giving rabbit urine against TuMV attack of kai Lan and to know the effect on growth and production of kai lan. Research conducted in the Organic Community Brenjonk Mojokerto regency, East Java. The research was conducted from February to April 2016. The Research used randomized block design (RBD) with six treatments and each treatment was repeated four times. The observation variable are include incubation period and symptoms of the disease, the intensity attack of disease, plant height, plant weigh, length, roots, and broad leaf of plants. The result of observation showed that rabbit urine with a consentrate $8 \mathrm{ml} / \mathrm{L}$ up to $32 \mathrm{ml} / \mathrm{L}$ applied as much as 8 times, can extend the incubation period and can't decrease the intensity of TuMV attack. Rabbit urine with a consentrate $8 \mathrm{ml} / \mathrm{L}$ up to $32 \mathrm{ml} / \mathrm{L}$ also applied as much as 8 times on the plant can increase the growth and production of kai lan include fresh weight of plant, plant height, plant root length and leaf area of plant.

Key words : Rabbit urine, Turnip Mosaic Virus (TuMV), kai lan, organic 


\section{PENDAHULUAN}

Tanaman kailan (Brassica oleraceae var. alboglabra) merupakan salah satu jenis sayuran suku kubis-kubisan (Brassicaceae) yang berasal dari negeri China. Tanaman kailan termasuk jenis sayuran daun dengan kandungan gizi tinggi yang dibutuhkan oleh tubuh manusia seperti protein, mineral, dan vitamin. Selain itu, nilai ekonomi kailan cukup tinggi. Menurut Krisnawati et al. (2014), tanaman kailan memiliki potensi tinggi untuk dikembangkan di Indonesia. Sehingga, hal ini menuntut tanaman kailan yang diproduksi harus bersih dan terbebas dari penggunaan bahan kimia.

Sistem budidaya yang dapat menghasilkan produk berkualitas tinggi yaitu budidaya tanaman kailan secara organik, karena tanaman yang ditanam secara organik akan menciptakan agroekosistem yang optimal dan lestari berkelanjutan sehingga memperoleh hasil yang baik secara sosial, ekologi dan ekonomi. Budidaya tanaman kailan secara organik membutuhkan pemeliharaan yang intensif, namun pada kenyataan di lapang permasalahan hama dan penyakit sering terjadi pada budidaya tanaman kailan. Menurut Provvidenti (1996), penyakit yang sering diderita tanaman kailan yaitu penyakit mosaik yang disebabkan oleh Turnip Mosaic Virus (TuMV).

TuMV merupakan jenis virus dari genus Potyvirus dalam faimili Potyviridae. TuMV menginfeksi berbagai spesies tanaman, sebagian besar dari Famili Brassicaceae. Virus ini termasuk penyakit penting karena dapat merugikan secara ekonomis bahkan dapat menyebabkan gagal panen. Sesuai dengan pernyataan Kartiningtyas (2006), bahwa TuMV telah mengakibatkan gagal panen pada lahan budidaya caisin di Desa Methuk, Kabupaten Boyolali, Jawa Tengah, dengan kejadian penyakit sampai 100\% pada tahun 2005.

Tanaman kailan yang terserang oleh virus mosaik dapat ditekan dengan menambahkan unsur hara kalium dan fosfor. Kondisi tanaman yang kekurangan unsur hara kalium menyebabkan komponen ketahanannya terganggu, sehingga akan memudahkan penetrasi patogen pada daun. Menurut Agrios (1996), Tanaman yang kekurangan kalium dapat menurunkan produksi silika pada sel epidermis, sehingga penetrasi penyebab penyakit pada jaringan sel lebih mudah. Sedangkan, tanaman yang kekurangan unsur hara fosfor akan menyebabkan pertumbuhan tanaman menjadi terhambat. Hal ini sesuai dengan pernyataan Sutedjo (2002), yang menjelaskan bahwa Fungsi unsur hara fosfor yaitu untuk pembentukan bunga, buah, biji, dan merangsang pertumbuhan akar.

Tanaman yang kekurangan unsur $P$ akan menyebabkan tanaman tumbuh kerdil, pembungaan dan pembentukan biji terhambat, serta tanaman menjadi lemah. Selain itu, unsur hara nitrogen juga sangat dibutuhkan oleh tanaman untuk pertumbuhan tanaman dalam pembentukan bagian vegetatif tanaman seperti daun, batang, dan akar serta berperan penting pada saat tanaman melakukan fotosintessis sebagai pembentuk klorofil. Fase pertumbuhan vegetatif tanaman berhubungan dengan tiga proses penting yaitu pembelahan sel, pemanjangan sel, dan tahap pertama dari diferensiasi sel. Ketiga proses tersebut membutuhkan karbohidrat, karena karbohidrat yang terbentuk akan bersenyawa dengan senyawa-senyawa nitrogen dalam pembentukan protoplasma pada titik-titik tumbuh yang akan mempengaruhi pertumbuhan tinggi tanaman, luas daun dan panjang akar tanaman. Ketersediaan karbohidrat yang dibentuk dalam tanaman dipengaruhi oleh ketersediaan hara bagi tanaman tersebut (Harlina, 2003).

Melihat permasalahan tersebut, pemberian pupuk organik cair dari urin kelinci dapat digunakan sebagai alternatif penambahan unsur hara di dalam tanah. Urin kelinci dapat digunakan sebagai pupuk pada budidaya secara organik untuk menjaga kesehatan tanah dan memperbaiki struktur tanah. Urin kelinci ini juga memiliki kandungan unsur hara yang lebih tinggi dibandingkan dengan urin hewan ternak lain sehingga dapat memberikan penambahan nutrisi yang baik bagi pertumbuhan tanaman dan dapat meningkatkan ketahanan tanaman. Berdasarkan hasil riset Badan Penelitian Ternak (Balitnak) (2005), telah diketahui kandungan unsur hara makro dan mikro urin kelinci unsur $\mathrm{N}, \mathrm{P}, \mathrm{K}$ rata-rata $(\mathrm{N}) 2,72 \%,(\mathrm{P}) 1,1 \%$, dan $(\mathrm{K})$ 0,5\% dan kandungan ini lebih tinggi jika dibandingkan dengan urin hewan ternak yang lain seperti sapi, kambing, domba, kuda dan babi. Dari uraian di atas, dapat diteliti pengaruh pemberian urin kelinci terhadap pertumbuhan dan serangan penyakit mosaik TuMV pada tanaman kailan. 


\section{METODOLOGI PENELITIAN}

\section{Tempat dan Waktu Penelitian}

Penelitian dilaksanakan pada bulan Februari 2016 sampai dengan bulan April 2016 di Rumah sayur organik (RSO) Komunitas Organik Brenjonk Desa Penanggungan, Kecamatan Trawas, Kabupaten Mojokerto dan Laboratorium Penyakit Tumbuhan jurusan Hama Penyakit Tumbuhan Fakultas Pertanian, Universitas Brawijaya, Malang.

\section{Alat dan Bahan}

Alat yang digunakan dalam penelitian adalah polibag $(3 \mathrm{~kg})$, cetok, gembor (8L), mortar, gelas ukur (1L), gelas ukur (10ml), selang air, timbangan analitik, gunting, tray, papan nama tiap perlakuan, cawan petri, botol semprot, kertas label, penggaris, meteran, plastik, alat tulis dan kamera. Bahan yang digunakan dalam penelitian ini adalah Inokulum TuMV dari tanaman pak coy hijau yang menunjukkan gejala spesifik mosaik dari lapang, Benih kailan varietas Winsa, benih tanaman indikator (Chenopodium amaranthicolor L.), tanah, karborundum 600 mesh, larutan buffer fosfat $0,001 \mathrm{M} \mathrm{pH} 7$, aquades steril, tissu steril, saringan (kain kasa steril), kapas, alkohol 70\%, air, dan pupuk organik cair dari proses fermentasi urin kelinci.

\section{Rancangan Penelitian}

Penelitian dilakukan menggunakan metode Rancangan Acak Kelompok (RAK) dengan enam perlakuan dan setiap perlakuan diulang sebanyak empat kali. Sehingga, diperoleh 24 perlakuan dan setiap perlakuan terdapat 2 tanaman yang digunakan sebagai tanaman uji. Berikut perlakuaan dalam penelitian ini:

PO: Kontrol atau tanpa pemberian pupuk organik cair urin kelinci dan tidak diinokulasi TuMV.

P1: Tanpa pemberian pupuk organik cair urin kelinci dan diinokulasi TuMV

P2: Pemberian pupuk organik cair urin kelinci $8 \mathrm{ml} / \mathrm{L}$ dan diinokulasi TuMV

P3: Pemberian pupuk organik cair urin kelinci $16 \mathrm{ml} / \mathrm{L}$ dan diinokulasi TuMV

P4: Pemberian pupuk organik cair urin kelinci $24 \mathrm{ml} / \mathrm{L}$ dan diinokulasi TuMV

P5: Pemberian pupuk organik cair urin kelinci $32 \mathrm{ml} / \mathrm{L}$ dan diinokulasi TuMV

\section{Persiapan Penelitian}

persiapan Media Tanam

Media tanam yang digunakan adalah tanah yang ditempatkan pada polibag ukuran $3 \mathrm{~kg}$ setiap perlakuan. Tanah yang digunakan adalah tanah yang tidak ditanami selama 3 bulan (tanah bero).

\section{Persiapan Tanaman Uji}

Benih yang digunakan yaitu Benih kailan varietas Winsa yang diperoleh dari Komunitas Organik Brenjonk. Benih Kailan terlebih dahulu direndam 1 jam untuk meluruhkan zat kimia yang menempel. Setelah itu ditiriskan dan dikeringkan dengan tissu, benih kailan kemudian disemaikan selama dua minggu hingga menjadi bibit yang siap dipindahkan ke polibag.

\section{Penyediaan Inokulum TuMV}

Penyediaan inokulum TuMV berasal dari tanaman pakcoy hijau varietas phak coy green yang diinokulasi dengan virus TuMV yang diperoleh dari laboratorium penyakit Tumbuhan. Phak coy hijau yang digunakan sebagai sumber inokulum menunjukkan gejala serangan mosaik dan malformasi.

\section{Persiapan Urin Kelinci}

Penyediaan Urin kelinci sesuai kebutuhan untuk aplikasi pada perlakuan dan ulangan yang digunakan. Sebelum mengaplikasikan urin kelinci ke polibag terlebih dahulu dilakukan analisis $\mathrm{N}, \mathrm{P}, \mathrm{K}$ total yang terkandung di dalam urin kelinci. Analisis unsur hara N, P, K dilakukan di Laboratorium Tanah Balai Pengkajian Teknologi Pertanian (BPTP) Jawa Timur. 


\section{Pelaksanaan Penelitian}

\section{Pemberian Pupuk Organik Cair (POC) Urin Kelinci}

Aplikasi pupuk organik cair urin kelinci sebagai perlakuan diberikan 1 minggu setelah bibit tanaman kailan dipindah tanamkan di lahan (RSO). Pupuk diaplikasikan 3 hari sekali atau 8 kali aplikasi hingga 1 minggu sebelum panen dengan konsentrasi sesuai perlakuan. Setiap polibag diberikan pupuk organik cair urin kelinci dengan volume $250 \mathrm{ml}$ yang telah dilarutkan dengan air.

\section{Pembuatan SAP TuMV}

Penularan virus TuMV dalam penelitian ini menggunakan cara mekanis yaitu dengan membuat sap dari inokulum TuMV. Mempersiapkan alat dan bahan telah disterilkan dengan alkohol 70\%. Daun tanaman pak coy hijau yang menampakkan gejala serangan Turnip Mosaic Virus dicuci, setelah itu dibersihkan kotoran yang masih menempel pada daun dengan tissue steril, dihilangkan dari tulang daunnya dan dipotong-potong. Kemudian diambil sebanyak 1 gram dan ditumbuk dengan mortar. Penumbukkan daun berfungsi untuk memecahkan sel pada daun untuk membantu keluarnya virus dari sel ke dalam cairan perasan. Kemudian ditambahkan buffer phospat 0,01 M, pH 7 sebanyak $10 \mathrm{ml}$. Pemberian buffer berfungsi untuk menetralkan virus dalam cairan perasan, khususnya terhadap pengaruh keasaman larutan yang dapat mempengaruhi persistensi virus dalam cairan perasan. Air perasan diperoleh dengan cara melakukan penyaringan menggunakan kain kasa steril.

\section{Penularan Virus Melalui SAP Pada Tanaman Uji (Tanaman Kailan)}

Penularan sap dilakukan pada daun tanaman kailan yang berumur 2 minggu setelah dipindahkan dari persemaian. Daun yang diinokulasi adalah daun muda yang telah terbuka sempurna. Sebelum diinokulasi, permukaan daun (2-3 helai daun) dilukai dengan cara ditaburi dengan karborandum 600 mesh. Pemberian karborundum ini bertujuan untuk menimbulkan luka mikroskopis pada dinding sel permukaan pada bagian tanaman yang diinokulasi. Setelah ditaburi dengan karborundum permukaan daun diusap perlahan-lahan menggunakan jari telunjuk.

Sap tanaman sakit dioleskan perlahan-lahan menggunakan cotton bat pada permukaan daun tanaman kailan dengan cara searah tulang daun. Inokulasi dengan cairan sap harus dilakukan dengan hati-hati untuk menghindari luka yang berlebihan. Setelah itu daun kailan yang telah diinokulasi didiamkan beberapa menit dan dilakukan pembasahan dengan meneteskan aquades pada daun yang diuji.

\section{Variabel Pengamatan}

Variabel yang diamati adalah masa inkubasi dan gejala penyakit TuMV, bobot basah tanaman, Tinggi tanaman, panjang akar tanaman, luas daun tanaman, dan intensitas serangan penyakit. Pengamatan intensitas serangan penyakit yang dilakukan dengan menggunakan perhitungan Intensitas serangan penyakit. Untuk menghitung intensitas serangan gejala virus mosaik menggunakan metode skoring menurut Abadi (2003) yang disajikan dalam Tabel 2. Perhitungan intensitas serangan menggunakan rumus yang dimodifikasi yaitu:

Keterangan:

$$
\mathrm{IP}=\frac{\sum(n \times v)}{N \times Z} \times 100 \%
$$

$P$ : Intensitas Serangan

$\mathrm{n}$ : Jumlah daun dalam tiap kategori

$v$ : Nilai skala tiap kategori serangan

$\mathrm{Z}$ : Nilai skala dari kategori serangan tertinggi

$\mathrm{N}$ : Jumlah daun yang diamati 
Tabel 1. Penilaian Skor daun tanaman sakit berdasarkan gejala mosaik dan malformasi dihitung dengan menggunankan skoring (Abadi, 2003).

\begin{tabular}{ll}
\hline Skor & \multicolumn{1}{c}{ Kategori serangan } \\
\hline 0 & Daun Sehat (Tidak menunjukkan gejala virus) \\
1 & Luas mosaik pada daun $\leq 25 \%$ \\
2 & Luas mosaik pada daun $>25 \% \leq 50 \%$ disertai melepuh \\
3 & Luas mosaik pada daun $>50 \%$ disertai melepuh dan malformasi \\
4 & Malformasi, daunnya melepuh dan kerdil \\
\hline
\end{tabular}

\section{Analisis Data}

Data pengamatan yang diperoleh dari hasil percobaan dianalisis dengan analisis ragam menggukan uji F. Apabila data menunjukkan pengaruh nyata dari perlakuan, maka dilanjutkan dengan Uji perbandingan antar perlakuan menggunakan uji Beda Nyata Terkecil (BNT) pada taraf $5 \%$.

\section{HASIL DAN PEMBAHASAN}

\section{Masa Inkubasi dan Gejala Serangan Turnip Mosaic Virus (TuMV) Pada Tanaman Indikator}

Berdasarkan hasil pengamatan pada tanaman indikator yang diinokulasi TuMV terdapat masa inkubasi yaitu lamanya keberhasilan virus masuk dan memperbanyak diri didalam jaringan tanaman. Tanaman inang yang dijadikan indikator adalah Chenopodium amaranticolor L. gejala muncul pada 8 hari setetah inokulasi. Gejala yang ditimbulkan yaitu gejala lesio lokal atau bercak yang membentuk spot-spot pada daun tanaman indikator (C. amaranticolor) yang diinokulasi TuMV (Gambar 1) . Hal ini sesuai dengan penelitian yang dilakukan oleh Choliq et al. (2018) bahwa C. amaranticolor yang terserang TuMV akan menimbulkan gejala yang nampak pada daun yaitu gejala lesio local nekrosis. Namun, dari gejala dan diagnosa tanaman C. amaranticolor yang disebabkan oleh TuMV menunjukkan gejala lokal klorotik lesio (bercak kuning hingga kemerahan berbentuk spot) dan tidak sistemik (Plant Virus Online, 2016).

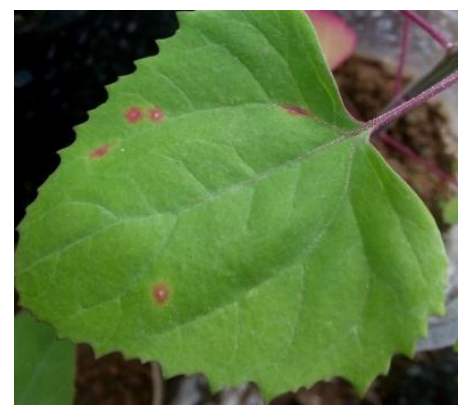

Gambar 1. Gejala lesion lokal pada C. amaranticolor yang diinokulasi TuMV

Hasil Penelitian Shabokkhiz et al., (2014), infeksi pada C. quinoa dan C. amaranticolor menunjukkan gejala lokal nekrotik spot pada daun yang diinokulasi TuMV pada 7 sampai 15 hari setelah inokulasi. Dalam hal ini, masa inkubasi virus TuMV pada tanaman inang sangat erat hubungannya dengan ketahanan suatu tanaman terhadap virus tersebut. Saat penelitian gejala muncul pada 8 hari setelah diinokulasi, diduga tanaman indikator yang digunakan rentan terhadap virus TuMV yang digunakan untuk inokulasi.

\section{Masa inkubasi dan Gejala serangan Turnip Mosaic Virus (TuMV) pada Tanaman Kailan}

Berdasarkan hasil analisis ragam dapat diketahui bahwa ada perbedaan yang nyata tentang pengaruh pemberian pupuk oraganik cair urin kelinci terhadap masa inkubasi serangan TuMV pada tanaman kailan. Nilai rerata masa inkubasi serangan TuMV pada tanaman kailan dapat dilihat pada Tabel 2. 
Tabel 2. Pengaruh POC urin kelinci terhadap rerata masa inkubasi serangan TuMV

\begin{tabular}{lc}
\multicolumn{1}{c}{ Perlakuan } & Rerata Masa Inkubasi (HSI) \\
\hline P0: Tanpa POC urin kelinci & - \\
P1: Tanpa POC urin kelinci + inokulasi TuMV & $6,50 \mathrm{a}$ \\
P2: POC urin kelinci $8 \mathrm{ml} / \mathrm{L}+$ inokulasi TuMV & $10,50 \mathrm{ab}$ \\
P3: POC urin kelinci $16 \mathrm{ml} / \mathrm{L}+$ inokulasi TuMV & $8,75 \mathrm{a}$ \\
P4: POC urin kelinci $24 \mathrm{ml} / \mathrm{L}+$ inokulasi TuMV & $9,37 \mathrm{a}$ \\
P5: POC urin kelinci $32 \mathrm{ml} / \mathrm{L}+$ inokulasi TuMV & $14,62 \mathrm{~b}$
\end{tabular}

Keterangan : Angka diikuti huruf yang sama pada kolom menunjukkan tidak berbeda nyata berdasarkan uji $\operatorname{BNT}(\alpha=5 \%)$

Hasil uji Beda Nyata Terkecil (BNT) taraf 5\% pada Tabel 2. menunjukan bahwa perbedaan perlakuan pemberian pupuk organik cair urin kelinci memberikan pengaruh yang signifikan terhadap masa inkubasi yaitu P5 (14,62 hsi) menunjukkan nilai yang berbeda nyata dengan P1 (6,50 hsi), P3 $(8,75 \mathrm{hsi})$ dan P4 (9,37 hsi), namun rerata pada P5 (14,62 hsi) tidak menunjukkan perbedaan yang nyata dengan P2 (10,50 hsi).

Masa inkubasi tercepat terdapat pada P1 (Tanpa pemberian poc urin kelinci dan inokulasi TuMV) dengan nilai rerata 6,50 hari setelah inokulasi. Sedangkan masa inkubasi paling lama tedapat pada P5 (Pemberian poc urin kelinci $32 \mathrm{ml} / \mathrm{L}$ dan inokulasi TuMV) dengan nilai rerata 14,62 hari setelah inokulasi, Hal ini diduga bahwa pupuk organik cair urin kelinci dapat memperlambat munculnya virus TuMV, jadi semakin tinggi pupuk yang diberikan maka semakin sulit virus bereplika dalam jaringan tanaman kailan. Masa inkubasi terhadap munculnya gejala TuMV pada tanaman kailan berkisar selama 7-14 hari. Sesuai dengan penelitian yang dilakuan oleh Sa'idah (2013), bahwa gejala TuMV dari tanaman sawi hijau (Suku Brassicaceae) yang diuji muncul antara 9 - 14 hari setelah inokulasi.

Gejala penyakit yang disebabkan oleh serangan TuMV pada tanaman kailan yaitu menunjukkan gejala malformasi (daun berkerut) dan mosaik (klorosis) pada daun tanaman setelah diinokulasi (Gambar 2). Menurut Tomlinson (1987), bahwa inokulasi TuMV pada tanaman Brassicaceae (kubis-kubisan) pada awalnya akan menyebabkan bercak klorotik pada daun yang diinokulasi, diikuti gejala belang, kemudian vein clearing yang sistemik, mosaik atau nekrosis, daun mengerut dan akhirnya mengecil. Pada beberapa kultivar Brassica terjadi nekrosis berat pada daun, petiol dan batang oleh beberapa isolat virus yang menyebabkan tanaman menjadi mati.
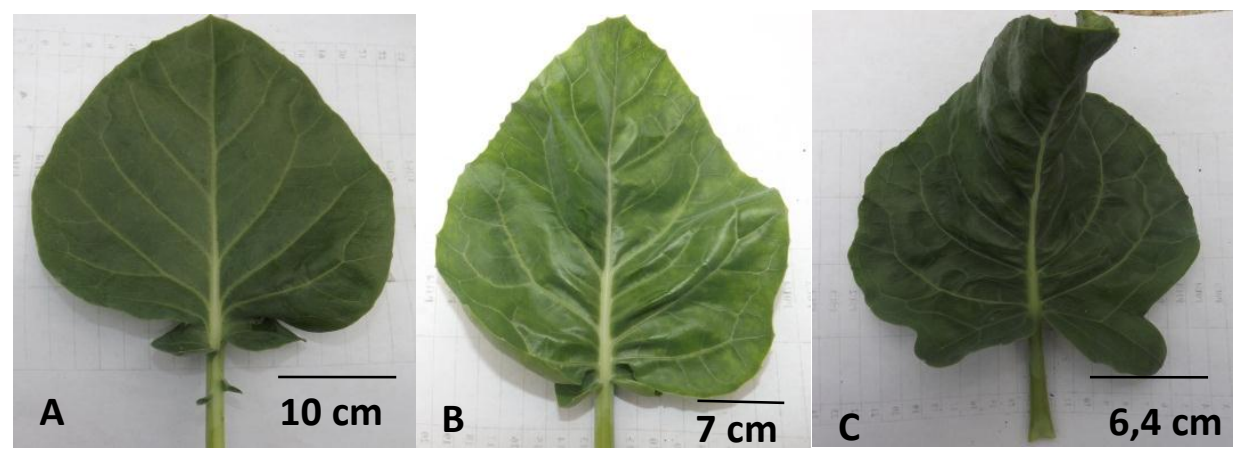

Gambar 2. Variasi gejala pada tanaman kailan terinfeksi TuMV; Daun yang sehat (A), mosaik ringan (B), dan malformasi (C).

Intensitas Serangan TuMV pada Tanaman Kailan

Berdasarkan hasil analisis ragam dapat diketahui tidak adanya perbedaan pengaruh pemberian pupuk oraganik cair urin kelinci terhadap intensitas serangan TuMV pada tanaman kailan (Tabel 3). Tabel 3 menunjukan bahwa perbedaan pelakuan pemberian pupuk organik cair urin kelinci tidak memberikan pengaruh yang signifikan terhadap intensitas serangan TuMV. Nilai rerata intensitas serangan terbesar tedapat pada P1 (Tanpa pemberian poc urin kelinci dan inokulasi TuMV) 
dengan nilai rerata $13,66 \%$. Sedangkan nilai rerata intensitas serangan terkecil tedapat pada P4 (Pemberian poc urin kelinci $24 \mathrm{ml} / \mathrm{L}$ dan inokulasi TuMV) dengan nilai rerata 5,40\%.

Tabel 3. Pengaruh POC urin kelinci terhadap rerata intensitas serangan TuMV pada tanaman kailan

\begin{tabular}{lc}
\hline \multicolumn{1}{c}{ Perlakuan } & Rerata Intensitas Serangan (\%) \\
\hline P0: Tanpa POC urin kelinci & - \\
P1: Tanpa POC urin kelinci + inokulasi TuMV & 13,66 \\
P2: POC urin kelinci 8 ml/L + inokulasi TuMV & 10,04 \\
P3: POC urin kelinci $16 \mathrm{ml} / \mathrm{L}+$ inokulasi TuMV & 9,02 \\
P4: POC urin kelinci $24 \mathrm{ml} / \mathrm{L}+$ inokulasi TuMV & 5,40 \\
P5: POC urin kelinci $32 \mathrm{ml} / \mathrm{L}+$ inokulasi TuMV & 6,28 \\
\hline
\end{tabular}

Keterangan : Angka diikuti huruf yang sama pada kolom menunjukkan tidak berbeda nyata berdasarkan uji $\operatorname{BNT}(\alpha=5 \%)$

Pada umumnya saat tanaman terserang patogen, tanaman akan membentuk suatu sistem kekebalan atau imunitas. Tanaman yang tahan biasanya dilengkapi dengan struktur pencegahan maupun mekanisme induksi untuk melakukan perlawanan atau pertahanan diri dari serangan patogen. Sistem pertahanan tumbuhan sangat bergantung pada interaksi inang, patogen dan lingkungan (Triwibawa et al., 2015).

Hasil dari uji laboratorium tanah BPTP (Balai Pengkajian teknologi Pertanian) Jawa Timur menunjukkan bahwa kandungan unsur hara yang terkandung dalam pupuk organik cair urin kelinci yang diaplikasikan yaitu kadar N 0,06\%, Kadar P 0,01\% dan kadar K 0,08\%. Kadar unsur hara kalium memiliki kadar yang paling tinggi yaitu 0,08\% dibandingkan dengan kadar unsur hara $\mathrm{N}$ dan $\mathrm{P}$, namun nilai kadar kalium tersebut masih tergolong rendah karena persentase dari kadar unsur hara urin kelinci yang diaplikasikan juga rendah. Unsur hara kalium sangat berpengaruh terhadap ketahanan tanaman terhadap penyakit. Karena, kondisi tanaman yang kekurangan kalium menyebabkan komponen ketahanannya terganggu, sehingga akan memudahkan penetrasi patogen pada daun (Ismunadji et al., 1976).

\section{Bobot Basah Tanaman Kailan}

Berdasarkan hasil analisis ragam dapat diketahui adanya perbedaan pengaruh pemberian pupuk oraganik cair urin kelinci terhadap bobot basah tanaman kailan. Nilai rerata bobot basah tanaman kailan dapat dilihat pada Tabel 4.

Tabel 4. Pengaruh POC urin kelinci terhadap rerata bobot basah tanaman kailan

\begin{tabular}{lc}
\multicolumn{1}{c}{ Perlakuan } & Rerata Bobot Basah (g) \\
\hline P0: Tanpa POC urin kelinci & $59,38 \mathrm{ab}$ \\
P1: Tanpa POC urin kelinci + inokulasi TuMV & $51,88 \mathrm{a}$ \\
P2: POC urin kelinci $8 \mathrm{ml} / \mathrm{L}+$ inokulasi TuMV & $67,50 \mathrm{abc}$ \\
P3: POC urin kelinci $16 \mathrm{ml} / \mathrm{L}+$ inokulasi TuMV & $75,62 \mathrm{bcd}$ \\
P4: POC urin kelinci $24 \mathrm{ml} / \mathrm{L}+$ inokulasi TuMV & $80,00 \mathrm{~cd}$ \\
P5: POC urin kelinci $32 \mathrm{ml} / \mathrm{L}+$ inokulasi TuMV & $88,75 \mathrm{~d}$ \\
\hline
\end{tabular}

Keterangan : Angka diikuti dengan huruf yang sama pada kolom menunjukkan tidak berbeda nyata berdasarkan uji BNT ( $\alpha=5 \%)$

Hasil uji Beda Nyata Terkecil (BNT) taraf 5\% pada Tabel 4. menunjukkan bahwa perbedaan pelakuan pemberian pupuk organik cair urin kelinci memberikan pengaruh pada rerata bobot basah tanaman kailan yaitu P5 (88,75 g) yang diperoleh tidak berbeda nyata dengan nilai rerata P0 $(59,38$ g), P2 (67,5 g), P3 (75,62 g) dan P4 (80 g), namun nilai rerata P5 (88,75 g) menunjukkan nilai yang berbeda nyata dengan nilai rerata P1 (51,88 g). Nilai rerata bobot basah tanaman kailan terbesar diperoleh dengan perlakuan P5 (pemberian poc urin kelinci $32 \mathrm{ml} / \mathrm{L}$ dan inokulasi TuMV) dengan nilai rerata $88,75 \mathrm{~g}$ dan nilai rerata bobot basah tanaman kailan terkecil tedapat pada P1 (tanpa pemberian poc urin kelinci dan inokulasi TuMV) dengan nilai rerata 51,88 g. Adanya berbedaan hasil bobot basah tanaman kailan dari keenam perlakuan tersebut, karena terdapat perbedaan dalam pemberian pupuk organik cair urin kelinci sehingga jumlah kandungan unsur hara yang diberikan dan diserap oleh tanaman juga mengalami perbedaan. 
Semakin tinggi dosis pupuk yang diberikan maka hasil bobot basah tanaman kailan semakin meningkat. Hal ini dapat dilihat pada pemberian pupuk organik cair urin kelinci pada dosis $16 \mathrm{ml} / \mathrm{L}$ hingga $32 \mathrm{ml} / \mathrm{L}$ dapat memberikan hasil yang semakin meningkat. Sesuai dengan pernyataan Rizqiani et al., (2007), bahwa pemberian pupuk organik cair mampu meningkatkan status unsur nitrogen dari harkat sangat rendah pada tanaman yang tidak diberi pupuk organik cair. Keadaan ini menyebabkan tanaman dapat meningkatkan hasil tanaman yang berupa bobot segar tanaman.

\section{Tinggi Tanaman Kailan}

Berdasarkan hasil analisis ragam dapat diketahui adanya perbedaan pengaruh pemberian pupuk oraganik cair urin kelinci terhadap tinggi tanaman kailan. Nilai rerata tinggi tanaman kailan dapat dilihat pada Tabel 5.

Tabel 5. Pengaruh POC urin kelinci terhadap tinggi tanaman kailan

\begin{tabular}{lc}
\hline \multicolumn{1}{c}{ Perlakuan } & Rerata Tinggi Tanaman $(\mathrm{cm})$ \\
\hline P0: Kontrol & $23,35 \mathrm{ab}$ \\
P1: Tanpa POC urin kelinci + inokulasi TuMV & $20,80 \mathrm{a}$ \\
P2: POC urin kelinci 8 ml/L + inokulasi TuMV & $23,84 \mathrm{~b}$ \\
P3: POC urin kelinci 16 ml/L + inokulasi TuMV & $24,93 \mathrm{bc}$ \\
P4: POC urin kelinci 24 ml/L + inokulasi TuMV & $25,33 \mathrm{bc}$ \\
P5: POC urin kelinci $32 \mathrm{ml} / \mathrm{L}+$ inokulasi TuMV & $26,70 \mathrm{c}$ \\
\hline
\end{tabular}

Keterangan : Angka diikuti dengan huruf yang sama pada kolom menunjukkan tidak berbeda nyata berdasarkan uji BNT ( $\alpha=5 \%)$.

Hasil uji Beda Nyata Terkecil (BNT) taraf 5\% pada Tabel 5. menunjukan bahwa perbedaan pelakuan pemberian pupuk organik cair urin kelinci memberikan pengaruh terhadap rerata tinggi tanaman kailan, pada P5 diperoleh tinggi tanaman sebesar $26,7 \mathrm{~cm}$ yang tidak berbeda nyata dengan nilai rerata P0 $(23,35 \mathrm{~cm})$, P3 $(24,93 \mathrm{~cm})$ dan P4 $(25,33 \mathrm{~cm})$, namun nilai rerata P5 $(26,7 \mathrm{~cm})$ menunjukkan nilai yang berbeda nyata dengan nilai rerata $P 1(20,8 \mathrm{~cm})$ dan P2 $(23,84 \mathrm{~cm})$. Nilai rerata tinggi tanaman kailan terbesar tedapat pada P5 (pemberian poc urin kelinci $32 \mathrm{ml} / \mathrm{L}$ dan inokulasi TuMV) dengan nilai rerata $26,7 \mathrm{~cm}$ dan nilai rerata tinggi tanaman kailan terkecil tedapat pada P1 (tanpa pemberian poc urin kelinci dan inokulasi TuMV) dengan nilai rerata 20,8 cm. Hasil nilai rerata tinggi tanaman dapat dilihat bahwa semakin tinggi jumlah konsentrasi pupuk organik cair yang diberikan maka semakin tinggi juga tinggi tanaman kailan. Dalam penelitian yang dilakukan Rosdiana (2015), bahwa pemberian pupuk organik cair urin kelinci $12 \mathrm{ml} /$ liter dapat memacu pertumbuhan tanaman pak coy paling optimal dibandingkan dengan perlakuan lain dengan dosis dibawahnya. Hal ini diduga, karena pemberian unsur nitrogen $(\mathrm{N})$ yang diserap oleh akar digunakan untuk pertumbuhan secara keseluruhan, terutama untuk pertumbuhan batang, cabang, dan daun. Jika dilihat pada pemberian pupuk organik cair urin kelinci pada konsentrasi $16 \mathrm{ml} / \mathrm{L}$ hingga $32 \mathrm{ml} / \mathrm{L}$ dapat memberikan hasil yang terus meningkat dan pengaruh yang berbeda dari perlakuan lainnya.

Hasil Hakim et al., (1986) dalam Annisava, (2013), menjelaskan bahwa nitrogen diperlukan untuk memproduksi protein dan bahan-bahan lainnya dalam proses pembentukan sel-sel serta berperan dalam pembentukan klorofil. Cukup tersedianya klorofil didaun akan menyebabkan daun mampu menyerap cahaya matahari, sehingga terjadi proses fotosintesis. Proses ini menghasilkan energi yang diperlukan oleh sel-sel untuk melakukan aktivitas, seperti pembelahan dan pembesaran sel. Proses pembelahan sel akan berjalan cepat seiring dengan ketersediaan nitrogen yang cukup. Nitrogen mempunyai peranan penting untuk merangsang pertumbuhan secara keseluruhan, khususnya pertumbuhan batang yang akan memacu pertumbuhan tinggi tanaman.

\section{Panjang Akar Tanaman Kailan}

Berdasarkan hasil analisis ragam dapat diketahui tidak adanya perbedaan pengaruh pemberian pupuk oraganik cair urin kelinci terhadap panjang akar tanaman kailan. Nilai rerata panjang akar tanaman kailan dapat dilihat pada Tabel 6. 
Tabel 6. Pengaruh POC urin kelinci terhadap rerata panjang akar tanaman kailan

\begin{tabular}{lc}
\hline \multicolumn{1}{c}{ Perlakuan } & Rerata Panjang akar $(\mathrm{cm})$ \\
\hline P0: Kontrol & 31,25 \\
P1: Tanpa POC urin kelinci + inokulasi TuMV & 36,11 \\
P2: POC urin kelinci $8 \mathrm{ml} / \mathrm{L}+$ inokulasi TuMV & 30,51 \\
P3: POC urin kelinci $16 \mathrm{ml} / \mathrm{L}+$ inokulasi TuMV & 32,98 \\
P4: POC urin kelinci $24 \mathrm{ml} / \mathrm{L}+$ inokulasi TuMV & 38,34 \\
P5: POC urin kelinci $32 \mathrm{ml} / \mathrm{L}+$ inokulasi TuMV & 39,39 \\
\hline
\end{tabular}

Keterangan : Angka diikuti huruf yang sama pada kolom menunjukkan tidak berbeda nyata berdasarkan uji $\operatorname{BNT}(\alpha=5 \%)$.

Tabel 6. menunjukan bahwa perbedaan perlakuan pemberian pupuk organik cair urin kelinci memberikan pengaruh yang signifikan terhadap nilai rerata panjang akar tanaman. Setiap perlakuan menunjukkan nilai yang berbeda, namun tetap dikatakan sama atau tidak berbeda nyata karena nilai f-tabel lebih besar dari nilai f-hitung. Nilai rerata panjang akar tanaman kailan terbesar terdapat pada P5 (pemberian poc urin kelinci $32 \mathrm{ml} / \mathrm{L}$ dan inokulasi TuMV) dengan nilai rerata $39,39 \mathrm{~cm}$. Nilai rerata intensitas serangan terkecil terdapat pada P2 (Pemberian poc urin kelinci $8 \mathrm{ml} / \mathrm{L}$ dan inokulasi TuMV) dengan nilai rerata $30,51 \mathrm{~cm}$. Hasil yang diperoleh tersebut tidak terjadi perberbedaan yang nyata.

Hasil dari uji laboratorium tanah BPTP (Balai Pengkajian Teknologi Pertanian) Jawa Timur menunjukkan bahwa kandungan unsur hara yang terkandung dalam pupuk organik cair urin kelinci yang diaplikasikan yaitu kadar N 0,06\%, Kadar P 0,01\% dan kadar K 0,08\%. Tauryska (2104), menyatakan bahwa organ yang berperan penting dalam penyerapan unsur hara adalah akar, panjang akar merupakan hasil perpanjangan sel-sel di belakang meristem ujung, dengan penambahan pupuk cair urin kelinci yang diberikan akan menyumbangkan unsur hara $\mathrm{P}$ (Fosfor) yang dapat memacu pertumbuhan akar sehingga akar dapat menyerap unsur hara yang dibutuhkan tanaman dengan baik. Namun, kadar unsur hara $\mathrm{P}$ (fosfor) yang diperoleh dari hasil uji laboratorium menunjukkan kandungan $\mathrm{P}$ yang rendah $(0,01 \%)$ sehingga hal tersebut menyebabkan pertumbuhan dan perkembangan akar yang diperoleh tidak signifikan.

\section{Luas Daun Tanaman Kailan}

Berdasarkan hasil analisis ragam dapat diketahui adanya perbedaan pengaruh pemberian pupuk oraganik cair urin kelinci terhadap luas daun tanaman kailan (Lampiran 8). Nilai rerata luas daun tanaman kailan dapat dilihat pada Tabel 7.

Tabel 7. Pengaruh POC urin kelinci terhadap rerata luas daun tanaman kailan

\begin{tabular}{lc}
\hline Perlakuan & Rerata Luas Daun $\left(\mathrm{cm}^{2}\right)$ \\
\hline P0: Kontrol & $83,62 \mathrm{ab}$ \\
P1: Tanpa POC urin kelinci + inokulasi TuMV & $75,99 \mathrm{a}$ \\
P2: POC urin kelinci $8 \mathrm{ml} / \mathrm{L}+$ inokulasi TuMV & $92,18 \mathrm{abc}$ \\
P3: POC urin kelinci $16 \mathrm{ml} / \mathrm{L}+$ inokulasi TuMV & $104,21 \mathrm{bcd}$ \\
P4: POC urin kelinci $24 \mathrm{ml} / \mathrm{L}+$ inokulasi TuMV & $116,17 \mathrm{~d}$ \\
P5: POC urin kelinci $32 \mathrm{ml} / \mathrm{L}+$ inokulasi TuMV & $114,28 \mathrm{~cd}$ \\
\hline
\end{tabular}

Keterangan: Angka diikuti dengan huruf yang sama pada kolom menunjukkan tidak berbeda nyata berdasarkan uji BNT $(\alpha=5 \%)$.

Hasil uji Beda Nyata Terkecil (BNT) taraf $5 \%$ pada Tabel 7. menunjukan bahwa rerata luas daun tanaman kailan dengan pelakuan pemberian pupuk organik cair urin kelinci memberikan pengaruh pada P4 $\left(116,17 \mathrm{~cm}^{2}\right)$ dan P5 $\left(114,28 \mathrm{~cm}^{2}\right)$ yang tidak berbeda nyata dengan nilai rerata P0 $\left(83,62 \mathrm{~cm}^{2}\right)$, P2 $\left(92,18 \mathrm{~cm}^{2}\right),\left(104,21 \mathrm{~cm}^{2}\right)$ dan P5 $\left(114,28 \mathrm{~cm}^{2}\right)$, namun nilai rerata P4 $\left(116,17 \mathrm{~cm}^{2}\right)$ menunjukkan nilai yang berbeda nyata dengan nilai rerata P1 $\left(75,99 \mathrm{~cm}^{2}\right)$. Nilai rerata luas daun tanaman kailan terbesar tedapat pada P4 (pemberian poc urin kelinci $24 \mathrm{ml} / \mathrm{L}$ dan inokulasi TuMV) 
dengan nilai rerata $116,17 \mathrm{~cm}^{2}$ dan nilai rerata luas daun tanaman kailan terkecil tedapat pada P1 (tanpa pemberian poc urin kelinci dan diinokulasi TuMV) dengan nilai rerata $75,99 \mathrm{~cm}^{2}$.

Adanya pemberian pupuk organik cair urin kelinci dengan konsentrasi pupuk yang berbeda memberikan hasil yang berbeda yakni semakin tinggi jumlah dosis pupuk yang diberikan maka nilai luas daun tanaman kailan yang diperoleh juga semakin meningkat. Hal ini diduga pemberian pupuk organik cair urin kelinci memicu pelebaran daun sehingga daun kailan dapat menangkap sinar matahari lebih optimal untuk proses fotosintesis dan menghasilkan fotosintat yang tinggi. Jika daun menghasilkan fotosintat yang tinggi maka akan berpengaruh dalam pertambahan luas daun tanaman kailan. Hal ini juga sesuai dengan pernyataan Fahrudin (2009), bahwa luas daun dan jumlah klorofil yang tinggi akan menyebabkan proses fotosintesis berjalan dengan baik. Semakin besar luas daun tanaman maka penerimaan cahaya matahari akan juga lebih besar. Cahaya merupakan sumber energi yang digunakan untuk melakukan pembentukan fotosintat. Luas daun yang tinggi, maka cahaya akan dapat lebih mudah diterima oleh daun dengan baik.

\section{Pembahasan Umum}

Aplikasi pupuk organik cair urin kelinci pada tanaman kailan memberikan pengaruh terhadap masa inkubasi dan gejala serangan pada tanaman indikator. Tanaman indikator yang diinokulasi virus TuMV yaitu tanaman C. amaranticolor. Gejala muncul saat 8 hari setelah inokulasi virus TuMV dengan bentuk gejala lesio lokal yang membentuk spot-spot pada daun tanaman yang diinfeksi virus TuMV. Hasil infeksi pada C. quinoa dan C. amaranticolor menunjukkan gejala lokal nekrotik spot pada daun yang diinokulasi TuMV pada 7 sampai 15 hari setelah inokulasi (Shabokkhiz et al., 2014). Hasil penelitian Kitajima, E. W. dan Costa, A.S (1973), juga pada tanaman C. quinoa yang berumur 2 sampai 3 minggu diinokulasi secara mekanis dengan isolate TuMV yang peroleh dari tanaman kale (Brassica oleracea var. acephala). Gejala yang muncul yaitu lokal klorotik lesio yang dapat dilihat pada daun yang diinokulasi pada 5 sampai 7 hari setelah inokulasi. Gejala lokal klorotik lesio ini juga terjadi pada tanaman indikator C. amaranticolor yang diinfeksi oleh TuMV.

Hasil dari analisa ragam masa inkubasi dan gejala serangan virus TuMV pada tanaman menunjukkan hasil yang berbeda nyata antara P1 (tanpa pemberian poc urin kelinci dan diinokulasi TuMV) dengan P5 (pemberian poc urin kelinci $32 \mathrm{ml} / \mathrm{L}$ dan diinokulasi TuMV). Perbedaan masa inkubasi setiap perlakuan diduga karena adanya perbedaan pemberian konsentrasi pupuk organik cair urin kelinci yang memiliki kandungan unsur kalium tertinggi $0,08 \%$ yang telah dilakukan uji laboratorium, walaupun persentase kalium tersebut tergolong rendah. Menurut Rauf et al., (2000), menyatakan bahwa fungsi unsur K pada tanaman salah satunya adalah membuat tanaman lebih tahan terhadap hama dan penyakit. Jadi lamanya gejala yang muncul dapat dikarenakan adanya ketahanan yang tinggi pada tanaman kailan dan pemberian pupuk cair urin kelinci yang mengandung jumlah unsur hara kalium yang tinggi.

Hasil pengamatan gejala serangan TuMV yang muncul pada tanaman kailan yaitu malformasi (daun berkerut) dan mosaik pada daun tanaman, namun tidak semua tanaman uji memunculkan suatu gejala yang jelas seperti pada tanaman kontrol tidak dilakukan inokulasi. Hal ini dikarenakan tidak terdapat vektor seperti Myzus persicae yang dapat menularkan virus dengan cepat dari tanaman yang diinokulasi virus TuMV, sehingga tidak memunculkan gejala pada tanaman kontrol. Gejala yang diperoleh dari seluruh tanaman yang diinokulasi TuMV juga tidak menunjukkan gejala yang berat karena diduga tanaman kailan memiliki ketahanan yang cukup tinggi sehingga virus TuMV tidak mudah penetrasi dan bereplika di dalam jaringan tanaman kailan. Matthews (1991), membedakan reakasi ketahanan tanaman terhadap infeksi virus menjadi tiga kelompok yaitu: 1) Tanaman yang resisten terhadap infeksi yang berupa reaksi hipersensitif yaitu tanaman inang bereaksi dengan memtikan sel-sel yang teralokasikan pada tempat yang diinokulasi tanpa penyebaran virus lebih lanjut; 2) Tanaman Toleran, ditandai virus dapat berepliksi dan menyebar dalam tanaman tetapi pengaruhnya terhadap hasil sangat sedikit; 3) Tanaman rentan, ditandai dengan gejala penyakit sangat jelas terlihat.

Ketahanan suatu tanaman juga sangat dipengaruhi oleh masa inkubasi dimana masa inkubasi ini menjadi penentu suatu tanaman dikatakan tahan atau rentan. Semakin lama masa 
inkubasi atau awal munculnya gejala virus maka tanaman tersebut semakin tahan. Hal ini berhubungan dengan mekanisme TuMV dalam menyerang tanaman secara sistemik yaitu infeksi virus pada tanaman bergantung pada sintesa virus karena infeksi tidak akan terjadi apabila virus tidak dapat penetrasi dan bermultiplika ke dalam jaringan inang. Virus penetrasi pada bagian tanaman tertentu (daun) karena terjadi luka mekanis.

Setelah virus mengalami kontak dengan sitoplasma dari sel tumbuhan yang peka maka virus akan melekat pada sel. RNA virus terlepas dari dari selubung protein dan menyebabkan infeksi. RNA yang masuk ke dalam sel akan merangsang pembentukan enzim-enzim RNA polymerase dan RNA replikasi. Laju penyebaran virus TuMV dari sel ke sel berbeda-beda dan bergantung pada jenis virus, umur sel tumbuhan yang terinfeksi dan interaksi dari keduanya, kecepatan infeksi lebih tinggi pada sel-sel yang muda dari pada sel-sel yang tua sehingga sangat berpengaruh pada lama munculnya gejala (Sastrahidayat, 2011). Pergerakan dan penyebaran virus TuMV didalam tanaman akan terjadi apabila terdapat kompabilitas antara virus dan inangnya sehingga terjadi gangguan metabolisme tanaman. Gangguan metabolisme tersebut dapat menyebabkan rusaknya membran sel, gangguan aktifitas kerja enzim inang sehingga reaksi kimia sel inang yang menyimpang dan bersifat pasif (Hadiastono, 2010).

Intensitas serangan TuMV yang terjadi pada tanaman kailan tidak menunjukkan hasil yang siginifikan atau hasil dari intensitas serangan TuMV tidak berbeda nyata, namun dari setiap perlakuan diperoleh nilai yang rendah hal ini diduga karena pemberian pupuk organik cair urin kelinci dan kondisi lingkungan yang optimal untuk pertumbuhan tanaman kailan, sehingga dapat mempengaruhi rendahnya nilai intensitas serangan TuMV meskipun hasil analisis anova yang diperoleh tidak berbeda nyata. Menurut Agrios (2005), mekanisme atau cara membuat kondisi yang tidak menguntungkan bagi perkembangan patogen tanaman salah satunya yaitu dengan cara pemilihan dan penambahan pupuk yang tepat, sehingga dapat merubah $\mathrm{pH}$ tanah yang berpengaruh tidak menguntungkan terhadap perkembangan patogen virus. Penambahan unsur hara yang tepat dan lingkungan yang mendukung dapat memicu pertumbuhan tanaman yang optimal sehingga tidak mudah terserang oleh patogen virus.

Penambahan unsur hara terutama unsur hara kalium, sangat penting untuk menjaga ketahanan tanaman sehingga patogen virus TuMV pada tanaman kailan tidak mudah menyebar dan bereplika di dalam jaringan tanaman dan menyebabkan intensitas serangan TuMV pada tanaman kailan tidak berbeda nyata atau berpengaruh secara signifikan. Unsur hara kalium juga dapat mempengaruhi berbagai tingkat perkembangan dan keberadaan patogen di dalam inang, secara tidak langsung mempengaruhi infeksi dengan mendorong penyembuhan luka dengan meningkatkan ketahanan terhadap kerusakan akibat serangan patogen (Agrios, 2005).

Variabel pengamatan pertumbuhan yang diamati yaitu bobot basah tanaman kailan. Pemberian pupuk organik cair urin kelinci dengan dosis paling tinggi yakni $32 \mathrm{ml} / \mathrm{L}$ memberikan pengaruh yang nyata dari perlakuan lainnya. Penelitian yang dilakukan Rosdiana (2015) menunjukkan bahwa pemberian pupuk organik cair urin kelinci $12 \mathrm{ml} /$ liter dapat memacu pertumbuhan tanaman pak coy paling optimal dibandingkan dengan perlakuan lain dengan dosis dibawahnya. Hal ini dikarenakan semakin tinggi konsentrasi pupuk yang diberikan pada tanaman maka semakin tinggi jumlah unsur hara yang terkandung di dalamnya. Setiap tanaman memiliki kebutuhan unsur hara berbeda-beda dan setiap pupuk organik urin kelinci juga memiliki jumlah kandungan unsur hara yang berbeda karena terdapat perbedaan pola makan kelincinya, jenis kelincinya dan urin yang dihasilkan kelinci itu sendiri. Sehingga dari literature di atas menunjukkan bahwa pemberian $12 \mathrm{ml} / \mathrm{L}$ urin kelinci terhadap tanaman pakcoy sudah memberikan hasil yang optimal, sedangkan hasil optimal ditunjukkan pada pemberian konsentrasi $32 \mathrm{ml} / \mathrm{L}$ pupuk organik urin kelinci pada tanaman kalian.

Jumlah konsentrasi pupuk organik yang semakin tinggi di dalam tanah maka akan semakin tinggi juga jumlah mikroorganisme menguntungkan bagi tanah dan tanaman. Sehingga jika kondisi tanah dan lingkungannya baik maka tanaman yang ditanam juga akan tumbuh dengan baik. Wood et al. (1997), menyatakan bahwa mikroorganisme yang menguntungkan akan menghasilkan metabolit 
yang mampu membantu mengkatalis energi di ekosistem, sehingga menjadikan lingkungan lebih sesuai bagi tanaman. Lingkungan yang lebih sesuai membuat pertumbuhan tanaman menjadi lebih baik, resisten terhadap patogen (virus), kurang disukai serangga, sehingga dapat memperpanjang umur tanaman.

Pertumbuhan tanaman yang baik seperti batang, daun dan cabang pada tanaman kailan dapat memicu tingginya nilai bobot basah tanaman. Menurut Annisava (2013), peningkatan bobot basah kailan merupakan total dari pertumbuhan bagian-bagian tanaman kailan itu sendiri, semakin baik pertumbuhan batang dan daun akan meningkatkan bobot segar yang selanjutnya akan meningkatkan poduksi. Hal ini juga selaras dengan pendapat Purnama (2013) bahwa semakin banyak jumlah daun, maka berat tanaman yang dikonsumsi akan meningkat. Meningkatnya berat tanaman yang dikonsumsi karena panjang daun dan klorofil. Semakin panjang daun maka semakin banyak jumlah klorofil sehingga fotosintesis akan berjalan lancar dengan adanya intensitas cahaya matahari yang cukup. Dengan meningkatkan hasil fotosintesis maka akan meningkatkan cadangan makanan untuk disimpan sehingga dapat mempengaruhi berat tanaman yang konsumsi.

Pengukuran tinggi tanaman dilakukan pada saat panen karena tanaman kailan memiliki batang yang bengkok dan titik tumbuhnya berada didalam sehingga mengalami kesulitan jika pengukuran dilakukan secara berkala. Dalam pengukuran tinggi tanaman ini, pupuk organik cair urin kelinci berperan penting dalam meningkatkan tinggi tanaman kailan. Dapat dilihat bahwa terjadi pengaruh yang nyata pada pemberian pupuk organik cair urin kelinci dengan dosis tertinggi yaitu 32 $\mathrm{ml} / \mathrm{L}$.

Semakin tinggi dosis pupuk organik cair urin kelinci yang diberikan, semakin meningkat pula tinggi tanaman karena terjadi pembesaran dan pembelahan sel yang baik dan optimal sehingga tinggi tanaman tersebut akan semakin meningkat. Menurut Lingga (1992), batang tanaman yang menghasilkan daun pada umumnya memiliki struktur reproduksi yang tegak lurus. Terjadinya pertambahan tinggi tanaman disebabkan karena adanya peristiwa pembelahan dan pemanjangan sel yang didominasi pada pucuk tanaman. Pertambahan tinggi tanaman berhubungan erat dengan penambahan jumlah daun, dimana pertambahan tinggi tanaman akan diikuti oleh pertambahan buku-buku batang yang merupakan tempat kedudukan daun tanaman. Proses ini memerlukan sintesis protein yang diperoleh tanaman dari lingkungan, terutama bahan organik di dalam tanah.

Labatar dan Hamzah (2006), juga menyatakan bahwa pemberian pupuk organik cair dalam jumlah yang sesuai dengan kebutuhan tanaman mendukung terjadinya pertumbuhan tanaman optimal yang menyebabkan proses pembelahan, pembesaran, dan pemanjangan sel akan berlangsung dengan cepat yang mengakibatkan beberapa organ tanaman tumbuh dengan cepat. Sehingga patogen virus tidak mudah penetrasi ke jaringan tanaman dan menghambat pertumbuhan tanaman.

Hasil pengukuran panjang akar tanaman dilakukan pada saat panen dengan nilai rerata panjang akar tanaman tidak mengalami perbedaan yang signifikan. Pemberian pupuk organik cair urin kelinci menunjukkan nilai yang tidak berbeda nyata antar perlakuan, namun masih mengalami peningkatan panjang akar tanaman. Jadi semakin tinggi dosis pupuk yang diberikan maka panjang akar tanaman semakin meningkat meskipun peningkatan tersebut tidak signifikan. Diduga hal ini terjadi karena pupuk organik cair urin kelinci yang diaplikasikan memiliki kandungan unsur hara $\mathrm{P}$ yang paling rendah dibandingkan dengan unsur makro lainnya yaitu $0,01 \%$, sedangkan fungsi $P$ yaitu untuk meningkatkan pertumbuhan panjang akar tanaman sehingga penyerapan oleh akar tanaman menjadi tidak optimal karena unsur hara $\mathrm{P}$ yang terkandung di dalam pupuk cair urin kelinci tersebut sangat rendah.

Fahrudin (2009), menyatakan bahwa ketepatan distribusi dan pertumbuhan sistem perakaran merupakan respon terhadap perbedaan konsentrasi hara tanah, sehingga densitas tanah yang paling tinggi akan terjadi ditanah yang subur, semakin subur suatu tanah maka kerapatan dan densitas tanah semakin besar. Salah satu variasi gejala penyakit TuMV adalah tanaman yang terserang umumnya mengalami penghambatan pertumbuhan sehingga tampak kerdil. Tanaman 
yang kerdil umumnya memiliki akar yang lebih pendek apabila dibandingkan dengan akar pada tanaman yang sehat (Sa'idah et al., 2013).

Pengukuran luas daun tanaman juga diukur pada saat panen dengan menggunakan LAM (Leaf Area Meter). Pemberian pupuk organik cair urin kelinci memberikan pengaruh yang nyata pada dosis $24 \mathrm{ml} / \mathrm{L}$ dan $32 \mathrm{ml} / \mathrm{L}$. Jadi semakin tinggi dosis pemberian pupuk ang diberikan maka semakin tinggi juga nilai luas daun yang diperoleh. Hal ini diduga karena ketersediaan unsur-unsur yang dibutuhkan tanaman yang berada dalam keadaan cukup, maka hasil metabolismenya akan membentuk protein, enzim, hormon dan karbohidrat, sehingga pemanjangan dan pemesaran sel akan berlangsung baik dan cepat. Kemungkin dari patogen untuk menyerang dan menghambat pertumbuhan pada sel dan jaringan tanaman juga semakin kecil. Sesuai dengan penyataan Sukawati (2010), bahwa daun merupakan organ penting tanaman yang berperan dalam proses fotosintesis. Pada proses fotosintesis juga diperlukan aerasi yang baik pada media tanam agar dapat mendukung akar tanaman dalam menyerap air dan unsur hara secara optimal yang selanjutnya ditranslokasikan tanaman untuk proses metabolisme yang berperan dalam pertambahan luas daun.

\section{KESIMPULAN}

Pemberian pupuk organik cair urin kelinci dengan konsentrasi $8 \mathrm{ml} / \mathrm{L}$ sampai dengan $32 \mathrm{ml} / \mathrm{L}$ yang diaplikasikan sebanyak 8 kali, dapat memperpanjang masa inkubasi namun tidak dapat menurunkan intensitas serangan TuMV. Pemberian pupuk organik cair urin kelinci dengan konsentrasi $8 \mathrm{ml} / \mathrm{L}$ sampai dengan $32 \mathrm{ml} / \mathrm{L}$ yang diaplikasikan sebanyak 8 kali pada tanaman kailan, dapat mingkatkan pertumbuhan dan produksi tanaman kalian meliputi bobot basah tanaman, tinggi tanaman, panjang akar tanaman dan luas daun tanaman.

\section{DAFTAR PUSTAKA}

Abadi, A. L. 2003. Ilmu Penyakit Tumbuhan Jilid 3. Bayu media. Malang. p 135.

Agrios, G. N. 2005. IImu Penyakit Tumbuhan Edisi Kelima. Gajah Mada University Press: Yogyakarta. pp 302-305.

Annisava, A. R. 2013. Optimalisasi Pertumbuhan dan Kandungan Vitamin C Kailan (Brassica alboglabra L.) Menggunakan Bokashi serta Ekstrak Tanaman Terfermentasi. Fakultas Pertanian dan Peternakan Universitas Islam Negeri Sultan Syarif Kasim Riau. Jurnal Agroekoteknologi. 3 (2): 5-7.

Balai Penelitian Ternak. 2005. Pupuk Organik Kelinci Super. Organik Indonesia. Bogor.

Fahrudin, F. 2009. Budidaya Caisim (brassica juncea I.) menggunakan Ekstrak Teh dan Pupuk Kascing. Skripsi. Fakultas Pertanian. Universitas Sebelas Maret. Surakarta.

Choliq, F.A., Astono, T.H., Istiqomah, I., Fauziyah, M., 2018. Identifikasi Penyakit yang Disebabkan oleh Virus pada Tanaman Pepaya (Carica papaya L.) di Malang, Jawa Timur. Gontor AGROTECH Sci. J. 4, 87-105.

Hadiastono, T. 2010. Virologi Tumbuhan Dasar. Fakultas Pertanian Universitas Brawijaya. Malang. p 86.

Harlina, N. 2003. Pemanfaatan Pupuk Majemuk Sebagai Sumber Harabudidaya Terung Secara Hidroponik. Bogor: Fakultas Pertanian IPB.

Ismunadji, M., S. Partohardjono dan A.S. Karama. 1991. Fospor: Peranan dan Penggunaannya dalam Bidang Pertanian. P.T. Petrokimia Gresik dan Balai Penelitian Tanaman Pangan. Bogor.

Kartiningtyas, S. H. H., 2006. Deteksi Turnip Mosaic Virus pada Jaringan Benih dan Daun. J. hpt tropika, 6.

Krisnawati, D., S. Triyono, dan M. Zen Kadir. 2014. Pengaruh Aerasi Terhadap Pertumbuhan Tanaman Baby Kailan (Brassica oleraceae var. achepala) pada Teknologi Sistem Hidroponik 
Terapung di Dalam dan di Luar Greenhouse. Jurusan Teknik Pertanian. Fakultas Pertanian. Universitas Lampung.

Lingga, P. 1992. Petunjuk Penggunaan Pupuk. PT. Penebar Swadaya. Jakarta.

Matthews, R.E.F. 1991. Plant Virology. 3rd ed. (San Diego, CA: Academic Press).

Plant Virus Online. 2016. Description and Lists from Turnip Mosaic Potyvirus. Di Unduh di http://sdb.im.ac.cn/vide/descr855.htm. Di akses pada tanggal 11 Agustus 2016.

Provvidenti R, 1996. Turnip Mosaic Potyvirus. In: Brunt AA, Crabtree K, Dallwitz MJ, Gibbs AJ, Watson L, eds. Viruses of plants. Wallingford, UK: CABI, 1340-3.

Purnama. R.H. 2013. Pengaruh Dosis Pupuk Kompos Enceng Gondok dan Jarak Tanam terhadap Pertumbuhan dan Hasil Tanaman Sawi (Brassica juncea I.). INNOFARM: Jurnal Inovasi Pertanian 12 (2).

Rauf, A.W., T. Syamsuddin, dan S. R. Sihombing. 2000. Peranan Pupuk NPK pada Tanaman Padi. Loka Pengkajian Teknologi Pertanian. pp 211-219.

Rizqiani, N. F., E. Ambarwati, dan N. W. Yuwono,. 2007. Pengaruh Dosis dan Frekuensi Pemberian Pupuk Organik Cair terhadap Pertumbuhan dan Hasil Buncis (Phaseolus vulgaris L.) Dataran Rendah. Fakultas Pertanian. Universitas Gajdah Mada. Jurnal Ilmu Tanah dan Lingkungan 7 (1): 43-53.

Rosdiana. 2015. Pertumbuhan Tanaman Pakcoy Setelah Pemberian Pupuk Urin Kelinci. Fakultas Pertanian Universitas Muhammadiyah Jakarta. Jurnal Matematika, Saint, dan Teknologi 16 (1): 2-4 .

Sa'idah, E. Y., M. Martosudiro, T. Hadiastono. 2013. Ketahanan Lima Varietas Tanaman Sawi Hijau (Brassica Juncea L.) terhadap Infeksi Turnip Mosaic Virus (TuMV) Jurusan Hama dan Penyakit Tumbuhan. Fakultas Pertanian. Universitas Brawijaya. Jurnal HPT 1 (3): 13-14.

Sastrahidayat, I. R. 2011. Fitopatologi (Ilmu Penyakit Tumbuhan). Universitas Brawijya Press. Malang. pp 153-159.

Sutedjo, M. M. 2002. Pupuk dan Cara Penggunaan. Jakarta: Rineka Cipta.

Tauryska, E. M. 2014. Pengaruh Pemberian Pupuk Cair Hasil Fermentasi Kotoran Padat Kelinci Terhadap Pertumbuhan Sambiloto (Andrographis paniculata Nees.) Sebagai Sumber Belajar Biologi SMA Kelas XII. Progam Studi Pendidikan Biologi. Universitas Ahmad Dahlan. Yogyakarta. JUPEMASI-PBIO 1 (1): 87-88.

Tomlinson, J. A. 1987. Epidemology and Control of virus diseases of vegetables. Annals of Aplied Biology.

Triwibawa, N. A, M. Martosudiro, T. Hadiastono. 2015. Pengaruh Ekstrak Daun Beberapa Tanaman Non Inang terhadap Ketahanan Induksi TuMV (Turnip Mosaic Virus) pada Tanaman Sawi (Brassica rapa L.). Jurusan Hama dan Penyakit Tumbuhan. Program studi Agroekoteknologi. Fakultas Pertanian. Universitas Brawijaya. Jurnal HPT 3(2): 28-29.

Wood, M. T., R. Miles and P. Tahora. 1997. EM fermented Plant Extract and EM 5 for Controling Pickleworm (Diaphinia nitidalis) in organic Cucumber. In: proceeding of $5^{\text {th }}$ intl. Conf. On Kyusei Nature Farming. Bangkok. Thailand. p 207-208. 